\title{
Hydrological and vegetation response to climate change in a forested mountainous catchment
}

\author{
Emilie Beaulieu $^{1}$ (D) Yann Lucas $^{1} \cdot$ Daniel Viville $^{1} \cdot$ François Chabaux $^{1} \cdot$ \\ Philippe Ackerer $^{1} \cdot$ Yves Goddéris $^{2} \cdot$ Marie-Claire Pierret $^{1}$
}

Received: 17 October 2016/Accepted: 19 October 2016/Published online: 3 November 2016

(C) Springer International Publishing Switzerland 2016

\begin{abstract}
Vegetal cover and the water cycle are closely linked. The climate controls the distribution and productivity of terrestrial vegetation, and the vegetal cover type is a key determinant for evapotranspiration and global runoff. In this study, a dynamic vegetation model (LPJ) has been coupled with a 3D hydrogeological model (MODFLOW) to estimate, for the first time, the impact of climate change on a small forested temperate watershed (Strengbach, Vosges, France). The model, calibrated with monthly hydrological and climate data, is able to globally reproduce the observed vegetal cover distribution and the water cycle over the 1987-2009 period. The discrepancies between calculated and observed intra-annual discharge variations highlight the importance of processes such as snow formation, snowmelt, and catchment recharge after drought periods, as well as the impact of evapotranspiration. Longterm simulations extending up to the year 2100 have been performed with climatic output from the Meteo-France climate model ARPEGE/Climate (IPCC, 2007 scenario A1B). With a predicted increase in temperature of $2.6{ }^{\circ} \mathrm{C}$ and a rise in atmospheric $\mathrm{CO}_{2}$ concentration of $80 \%$, the mean annual precipitation decreases by $4.5 \%$ in the
\end{abstract}

Electronic supplementary material The online version of this article (doi:10.1007/s40808-016-0244-1) contains supplementary material, which is available to authorized users.

Emilie Beaulieu

emilie.beaulieu@engees.unistra.fr

1 Laboratoire d'Hydrologie et de Géochimie de Strasbourg, Université de Strasbourg/ENGEES-CNRS-UMR 7517, 1, rue Blessig, 67084 Strasbourg Cedex, France

2 Géoscience Environnement Toulouse (GET), CNRSUniversité de Toulouse III, Observatoire Midi-Pyrénées, 31400 Toulouse, France
Strengbach watershed over the course of the century. The models cascade predicts a limited decrease of evapotranspiration (by 2.5\%), an impact on discharge (11\% decrease) at the watershed outlet over the 21 st century, and a significant change in vegetation distribution starting in approximately 2085 . The response of land plants to climate change in the future seems to only slightly affect the water resources in the Strengbach catchment. This study also highlights existing shortcomings and limitations of simulations for measuring the impacts of climate change.

Keywords Hydrology · Evapotranspiration · Vegetation · Climate change $\cdot$ Modeling $\cdot$ Strengbach catchment

\section{Introduction}

Vegetal cover and the water cycle are intrinsically coupled. The water cycle controls the distribution and productivity of terrestrial vegetation (Stephenson 1990; Churkina et al. 1999), and in turn, the vegetal cover type is a key determinant for evapotranspiration and global runoff (Dunn and Mackay 1995). The runoff is constrained by vegetation through stomatal conductance (Field et al. 1995; Morison and Gifford 1983), root pattern, leaf area (Milly 1997; Betts et al. 1997), interception and transpiration (Leipprand and Gerten 2006; Beaulieu et al. 2010).

The impact of climate change on water resources and runoff is thought to be dependent on the responses of vegetation to temperature, atmospheric $\mathrm{CO}_{2}$ concentrations and precipitation variations. For the Northeastern region of France, global circulation models predict an increase in air temperature up to $4{ }^{\circ} \mathrm{C}$ and changes in precipitation patterns under the worst scenario (atmospheric $\mathrm{CO}_{2}$ doubling before the end of the 21st century) (IPCC 2014). These 
climate changes could influence ecosystems and alter the vegetation dynamics and consequently the water resources and ecosystems services in mountain regions (Björnsen Gurung 2007).

The response of vegetation to elevated $\mathrm{CO}_{2}$ concentrations could be an increase in carbon uptake by plants (fertilization effect). Previous studies based on modelling or experimental methods showed that stomatal conductance may decrease by as little as $25 \%$ (Field et al. 1995) or as much as $40 \%$ (Morison and Gifford 1983; Luo et al. 2013), since plants tend to close their stomata to maintain an optimal balance between water loss and $\mathrm{CO}_{2}$ absorption (Van de Geijn and Goudriaan 1997; Woodward 2002). Under a doubled $\mathrm{CO}_{2}$ concentration, global evapotranspiration is predicted to decrease by $7 \%$, while runoff and soil moisture are predicted to increase by 5 and $1 \%$, respectively (Leipprand and Gerten 2006).

At the global scale, the geographical distribution of vegetation plays a major role in the variability of annual runoff (Peel et al. 2001). Moreover, a reduction in forest cover leads to a decrease of evapotranspiration and thus an increase of runoff. In addition, global climate changes include changes in precipitation and temperature patterns, which can modify water quantity and quality at the watershed scale (Luo et al. 2013; Morán-Tejeda et al. 2014; Fan and Shibata 2015). Under constant precipitation, Bocchiola (2014) highlighted a decrease in discharge in Alpine catchments over the past decades due to increased temperatures and evapotranspiration. In mountainous regions, the decrease of snowfall and the concomitant increase of rainfall during the winter (Arnell 1999; Arnell and Gosling 2013), accompanied by an earlier melting of the snowpack in spring (Bavay et al. 2013), will increase the flood risk (Fan and Shibata 2015) and will modify groundwater recharge processes, water storage, and therefore, water availability.

The hydrological processes in mountains are thus highly sensitive to changes in climate, and a comprehensive understanding of these processes that control the water balance in mountainous regions is crucial to predict the impact of climate change on these fragile environments.

The aim of this study is to quantify the impact of future climatic changes on water resources and vegetation dynamics in the Strengbach catchment (located in the Vosges Mountains in France). This catchment has been monitored for more than 30 years (Observatoire HydroGéochimique de l'Environnement—ohge.unistra.fr). Its hydrological and geochemical functioning is well known, allowing for model calibration. We use a models cascade combining a dynamic vegetation model (LPJ) and a hydrogeological model (MODFLOW). We first calibrate the models cascade with monthly hydrological and climate data available over the 1987-2009 period. The originality of our approach lies in the direct comparison of the results of the models cascade with a long-term data series. Then, we use a simulation of the Météo-France ARPEGE climate model (A1B IPCC scenario) to project our models cascade over the years 2009-2098.

\section{Materials and methods}

\section{Model description}

\section{Cascade of two models: LPJ model and MODFLOW model}

Mean climate data (air temperature, precipitation, cloud cover, amount of wet days) measured monthly over the 1950-2009 period at the Strengbach watershed and additional data from Harris et al. (2014) are used to force the LPJ model to estimate water and carbon exchanges between atmosphere, vegetation and soil and to simulate the vegetal cover dynamic (Sitch et al. 2003). The vegetal cover and associated carbon fluxes (such as respiration or net primary production) reach a state of equilibrium after thirty years (1950-1980). The groundwater recharge for the 3D hydrogeological model on each grid cell is computed using precipitation (Prec) transpiration, interception (Int), and soil evaporation (Es), as calculated by the LPJ model (Fig. 1) for the whole watershed. The 3D hydrogeological model is run over the 1987-2009 period to estimate the monthly and annual discharge at the outlet of the Strengbach watershed.

\section{LPJ model}

The Lund-Potsdam-Jena Dynamic Global Vegetation Model (LPJ) is derived from the BIOME family of models, and combines a mechanistic representation of terrestrial vegetation dynamics with the calculation of the water and carbon exchanges between soil and the atmosphere (Haxeltine and Prentice 1996; Kaplan 2001). LPJ includes a numerical description of the vegetal cover structure and dynamic competition between plant functional types and soil biogeochemistry. Ten plant functional types (PFTs) are represented: eight forests and two herbaceous environments. The presence or absence as well as the fractional coverage of each PFT depend on individual bioclimatic limits as well as physiological and morphological parameters.

The LPJ model includes a box model representation of the soil (2 layers: a superficial layer from 0.0 to $0.5 \mathrm{~m}$, and a deep layer from 0.5 to $1.5 \mathrm{~m}$ ). The available water content and the water flux incorporated by roots are calculated for both soil layers. The PFT's transpiration depends on the photosynthetic activity, the soil water content and the 
Fig. 1 Schematic representation of water fluxes computed on Strengbach catchment by LPJ and MODFLOW models. The abbreviations of these water fluxes are defined in the text
LPJ

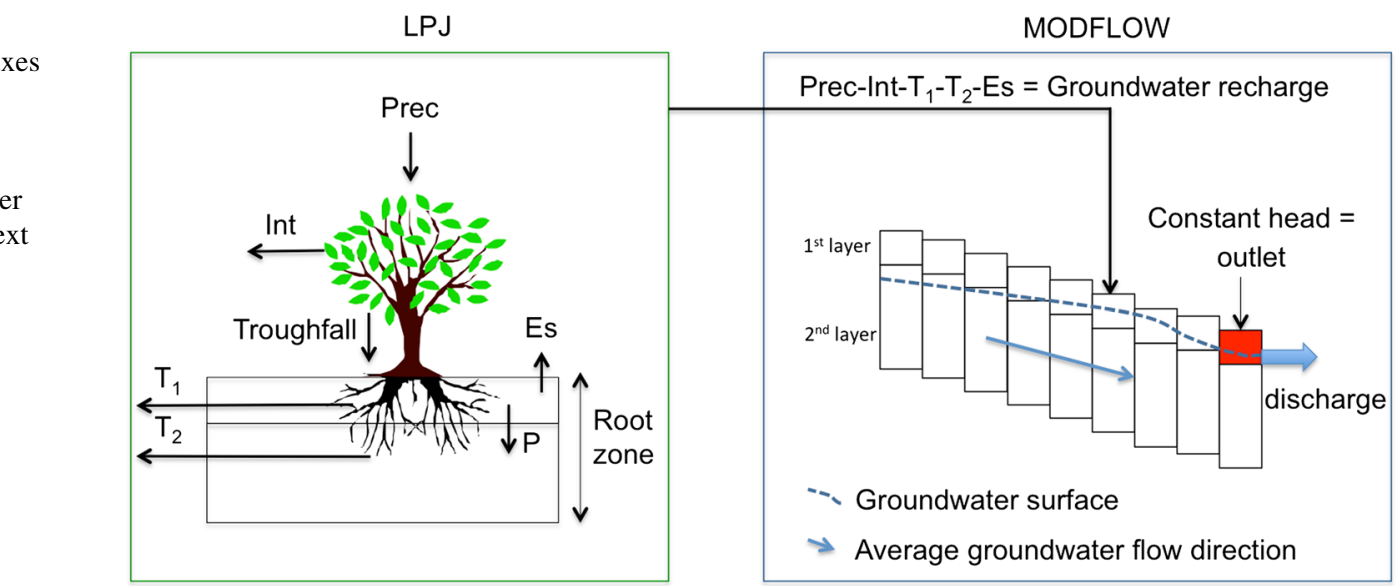

MODFLOW rooting pattern of the PFTs. The water content in the superficial soil layer is determined by the difference between input water fluxes (precipitation and/or snowmelt) and output water fluxes [interception, transpiration $\left(\mathrm{T}_{1}\right)$, percolation (P, Fig. 1) between two layers, and superficial runoff]. The precipitation falls as rain or snow, depending on the daily mean air temperature. All precipitation for days displaying negative temperatures is added to the snowpack. The snowpack begins to melt above $0{ }^{\circ} \mathrm{C}$ (Gerten et al. 2004). The water content in the deep soil layer is calculated as the difference between water percolation (depending on soil texture and layer thickness) and the water uptake by roots $\left(\mathrm{T}_{2}\right)$. The transpiration rate is related to the snow processes because the water available in the two layers depends on snowpack evolution, and the transpiration is calculated from the water content in the soil. Superficial and deep runoffs are calculated when the content exceeds the field capacity in layers 1 and 2 , respectively. The soil evaporation is calculated on the simulated fraction of the grid cell not covered by vegetation (Gerten et al. 2004).

The water fluxes depend on the characteristics of the PFTs established on site. The photosynthesis and soil water dynamics are simulated with a daily time step, while vegetal cover structure and PFT population densities are updated annually. The LPJ model is fully described in (Sitch et al. 2003). The LPJ model has been extensively validated against observations of vegetation structure, phenology, water and carbon fluxes as well as their seasonal variability (Lucht et al. 2002; Sitch et al. 2003; Gerten et al. 2004).

\section{Conceptual hydrogeological model}

Several studies have already used models to simulate the hydrological and geochemical behavior of the Strengbach catchment system (Goddéris et al. 2006; Viville et al. 2006), but no hydrogeological model has been applied until now. In this work, a groundwater model has been developed using the existing MODFLOW code to simulate the outlet discharge variations over 23 years. Previous studies (Ladouche et al. 2001; Viville et al. 2006) have shown that discharge variations are explained by the existence of two hydrological compartments with different hydrodynamic characteristics, with the higher compartment being more permeable than the lower one, which is also thicker and which contributes to the base flow. Therefore, the underground has been discretized into two layers of unconfined aquifers. At this stage of our understanding of the hydrogeological processes, the contribution of the vadose zone is neglected because its thickness is not relevant compared to the thickness of the lower hydrological compartments (see "Hydrogeological model calibration") (Ladouche et al. 2001; Viville et al. 2006). The Strengbach river is not explicitly accounted for because superficial runoff in the catchment is only significant in some areas near the outlet where the soil can be saturated. The total extension of those areas represents less than $3 \%$ of the total area (Ladouche et al. 2001).

The MODFLOW model is a numerical model based on Darcy's law and the mass conservation concept developed by McDonald and Harbaugh (1988). This model solves the three-dimensional groundwater flow equation for a porous medium using a finite-difference method:

$$
\frac{\partial}{\partial x}\left(K_{x x} \frac{\partial h}{\partial x}\right)+\frac{\partial}{\partial y}\left(K_{y y} \frac{\partial h}{\partial y}\right)+\frac{\partial}{\partial z}\left(K_{z z} \frac{\partial h}{\partial z}\right)-W=S_{s} \frac{\partial h}{\partial t}
$$

where $K_{x x}, K_{y y}$ and $K_{z z}$ are values of principal hydraulic conductivity along the $\mathrm{x}, \mathrm{y}$ and $\mathrm{z}$ coordinate axes, respectively; $h$ represents the piezometric head, and $W$ is a volumetric flux per unit volume representing sources and/or sinks of water. $S_{s}$ is the specific storage of the porous material, and $t$ is time. This is one of the most widely used models to simulate groundwater flow (e.g., Xu et al. 2012; Cho et al. 2009). 


\section{Study site description}

The Strengbach watershed ( $80 \mathrm{ha})$ is a small granitic catchment located on the eastern side of the Vosges Mountains (Northeast France) where hydro-geochemical processes have been monitored since 1986 (Riotte and Chabaux 1999; Chabaux et al. 2005; Rihs et al. 2011; Gangloff et al. 2014; Pierret et al. 2014). The topography ranges from $883 \mathrm{~m}$ at the outlet to $1146 \mathrm{~m}$ at the catchment divide (Fig. 2a). The mean slope of the Strengbach catchment is $15^{\circ}$. The climate is oceanic mountainous, with monthly mean temperatures ranging from -2 to $14{ }^{\circ} \mathrm{C}$ (Viville et al. 2012). The mean air temperature for the Strengbach catchment calculated for the years 1986-2012 is $6{ }^{\circ} \mathrm{C}$ (Hydro-geochemistry Observatory of Environment, OHGE data). The coldest month is January, with a mean temperature of $-1.5^{\circ} \mathrm{C}$, whereas August is the warmest month, with a mean temperature of $14{ }^{\circ} \mathrm{C}$. The mean annual precipitation is $1370 \mathrm{~mm}$ over the last three decades with large inter-annual variations (from 893 to $1713 \mathrm{~mm}$ ). However, the Strengbach catchment is characterized by low intra-monthly variability in precipitation due to the West-dominant wind regime. The mean annual discharge is $814 \mathrm{~mm}$, also displaying strong inter-annual variations ranging from 494 to $1132 \mathrm{~mm} / \mathrm{year}$. The highest flow rates occur during the cold period, and the lowest water discharges occur at the end of the summer season. The outlet discharge fluctuates from a few $1 / \mathrm{s}$ to several hundred $1 / \mathrm{s}$ during high flow discharge, corresponding generally to snowmelt (OHGE data). The forest covers $90 \%$ of the watershed area and consists of $80 \%$ spruces and $20 \%$

(a)

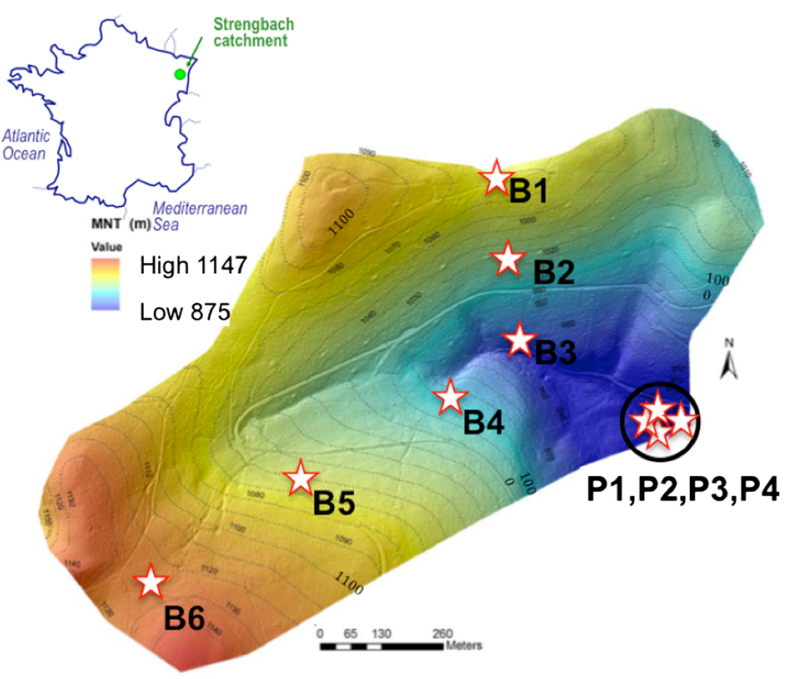

beeches. The bedrock is mainly composed of a hydrothermally altered Hercynian base-poor granite (332 $\pm 2 \mathrm{Ma})$ (Boutin et al. 1995), and of gneiss on the northern slope (Fig. 2b).

\section{Data acquisition}

\section{Climate data}

Climate data (atmospheric $\mathrm{CO}_{2}$ concentration, monthly air temperature, precipitation, amount of wet days, cloud cover) for the Strengbach watershed are provided by OHGE (for the years 1986-2009), and the CRU-TS 3.1 spatial climate data for the simulation over the twentieth century prior to 1986 , are set to a spatial resolution of $0.5^{\circ}$ latitude versus $0.5^{\circ}$ longitude (Harris et al. 2014). As in previous studies (François et al. 1998), we calculate the monthly mean anomalies to correct the monthly climate data from the CRU-TS database (details in supporting information). The same procedure is applied for future projections. The monthly precipitation, amount of wet days, and temperature are calculated using the MeteoFrance climate model ARPEGE/Climate (scenario A1B, middle scenario; Déqué 2007) for the years 1951-2098.

\section{Soil properties}

Soil information, including textural fraction (clay, silt, sand), bulk density, and porosity, was measured at the site. The mean compositions of the superficial layer $(0.0-0.5 \mathrm{~m})$ and deep layer $(0.5-1.5 \mathrm{~m})$ were $15 \%$ clay,

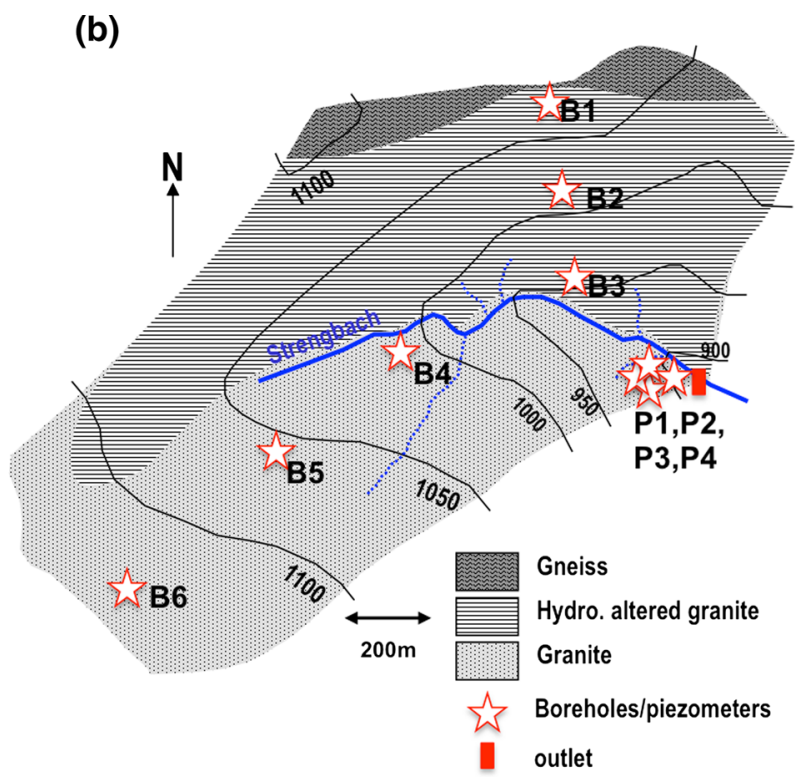

Fig. 2 Land numerical model representing the altitudes distribution (a) and map showing the bedrock types (b), of the Strengbach catchment with the boreholes (B1-B6)/piezometers (P1, P2, P3, P4) location 
Table 1 Hydraulic conductivity $(\mathrm{m} / \mathrm{s})$ and storage coefficient $(-)$ values of gneiss and granite bedrock as well as the references for these two parameters

\begin{tabular}{llll}
\hline $\begin{array}{l}\text { Rock } \\
\text { type }\end{array}$ & $\begin{array}{l}\text { Hydraulic } \\
\text { conductivity (m/s) }\end{array}$ & $\begin{array}{l}\text { Storage } \\
\text { coefficient (-) }\end{array}$ & References \\
\hline Gneiss & $3.10^{-12}$ to $3.10^{-4}$ & $10^{-4}$ to $3.10^{-3}$ & $\begin{array}{l}\text { Heath (1983), Stober (1997), Maréchal and Perrochet (2003), Sieber and Uhlenbrook } \\
\text { (2005), Abdelaziz and Merkel (2015) } \\
\text { Granite }\end{array}$ \\
$6.10^{-11}$ to $4.10^{-5}$ & $\begin{array}{c}6.10^{-8} \text { to } \\
3.10^{-2}\end{array}$ & $\begin{array}{c}\text { Rasmussen (1964), Heath and Durrance (1985), Morrice et al. (1997), Stober (1997), } \\
\text { Maréchal et al. (2003) }\end{array}$ \\
\hline
\end{tabular}

$19 \%$ silt, $66 \%$ sand, and $9 \%$ clay, $19 \%$ silt, $72 \%$ sand, respectively. They were determined from field values averaged over 35 samples from 4 weathering profiles that were geographically distributed on the two slopes of the watershed. The soil texture is used in the LPJ model to determine a soil type (Gerakis and Baer 1999). Parameters are assigned to each soil type, allowing for the calculation of the percolation.

The groundwater model MODFLOW was calibrated by assuming that the hydrodynamic parameters have constant values over defined zones. The geometry of the zones for the first layer were estimated using proton Magnetic Resonance Sounding (MRS) (Legchenko et al. 2011; Vouillamoz et al. 2015) campaigns in 2013 and 2015. MRS provides an estimate of the water content over approximately $10 \mathrm{~m}$ depths, and we assume that the water content variability is linked to the underground heterogeneity (Boucher et al. 2015). Five zones have been defined. The initial parameter values have been taken from the literature, accounting for the deep saprolitic layer type (Table 1). These parameter values have been changed during the groundwater model calibration (Fig. 4; "Hydrogeological model calibration"). For the second layer, for which MRS data give no information, the zones number has been reduced to four.

\section{Hydrogeological model calibration}

The boundary conditions of the model are a no-flow boundary set at the catchment limits, and a constant head at the outlet. If the lateral limits are known, the aquifer depth remains poorly defined. An arbitrary constant depth of $60 \mathrm{~ms}$ was chosen, consistent with a previous study (Viville et al. 2006), which suggests that the depth of the fractured granite extends over $45 \mathrm{~m}$.

A steady-state calibration of MODFLOW was first conducted over the Strengbach basin by using piezometers and water levels in numerous boreholes (Fig. 3). Two layers are considered (0-10 and 10-60 m depths; Fig. 4). Each layer is discretized into 5476 cells $(20 \mathrm{~m} \times 10 \mathrm{~m})$. The hydraulic conductivities of the two

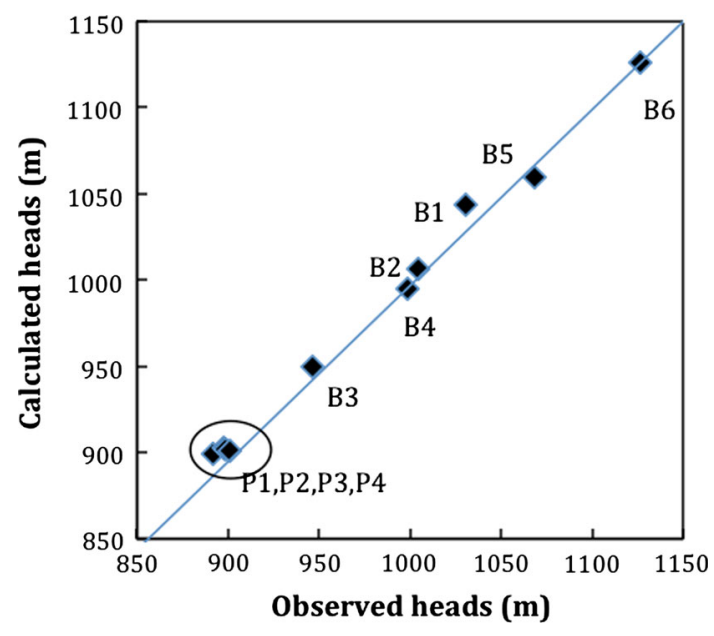

Fig. 3 Comparison between observed (in 2014) and calculated heads (m) for the available boreholes (B1-B6)/piezometers (P1, P2, P3, P4) in steady state

layers were calibrated independently. Hydraulic conductivity generally decreases with increasing depth (Carlsson and Olsson 1977; Stober 1997). Therefore, conductivity values are smaller than the first layer values, except for the northern zone, where the presence of gneissic rocks in the first layer can make it less permeable (Stober 1997).

Next, a transient simulation of the model was run to determine the discharge at the outlet. The run starts from the steady-state simulation, and the starting date is set at 1950. Storage coefficients were adjusted (Fig. 4) from the literature (Table 1). The storage coefficient of the second layer had to be set at very small values, particularly in the zone near the catchment outlet. Small values can be partially justified by the fact that the underlying granite is fractured and that these fractures tend to decrease storage dramatically (Spitz and Moreno 1996; Lucas and Vaute 2011). In the specific case of the outlet area, this means that the aquifer depth is probably smaller than the value assumed in the model $(60 \mathrm{~m})$. This is consistent with the fact that the zone closest to the outlet is a wetland. 
Layer 1

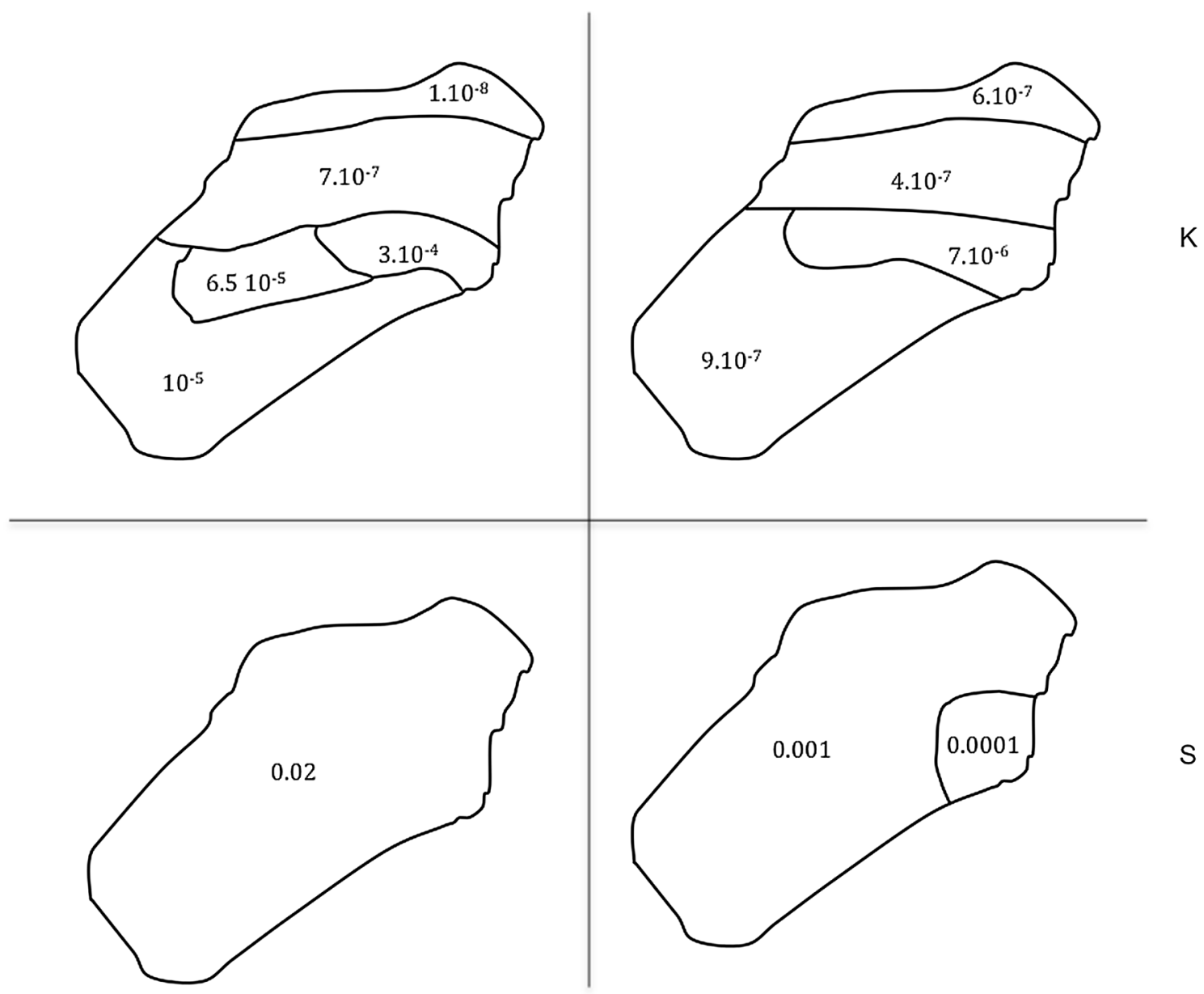

Layer 2

K $S$

Fig. 4 Hydrodynamic calibrated parameters: hydraulic conductivities $(\mathrm{K} ; \mathrm{m} / \mathrm{s})$ and storage coefficients $(\mathrm{S} ;-)$ of the two layers

\section{Results and discussion}

\section{Vegetation dynamic over the last two decades}

The simulated vegetal cover stabilizes after 30 simulated years. The LPJ model predicts that the forest covers $95 \%$ of the catchment area, consisting of $70 \%$ boreal evergreen PFT, and 30\% boreal summergreen PFT (deciduous forest). The temperate herbaceous PFT represents $5 \%$ of the watershed area over the 1987-2009 period. The distribution of plant species estimated by the LPJ model corresponds to that observed in the Strengbach watershed. The calculated mean biomass at steady state (4t/ha) matches the $3.7 \mathrm{t} / \mathrm{ha}$ measured for the 85 -year-old forest $(3.68 \mathrm{t} / \mathrm{ha}$; Le Goaster et al. 1991).

The transpiration (water flux taken up by roots in the two layers of the LPJ model) and the water flux intercepted by the vegetal cover represent 28 and $18 \%$, respectively, of the 1987-2009 average precipitation (Fig. 5). The evapotranspiration rate (approximately
$3.5 \mathrm{~mm} /$ day) is lower than that estimated by Viville et al. (1993) during the summer of $1989(1.5 \mathrm{~mm} /$ day $)$ on the Strengbach catchment but is of the same magnitude as those found at similar stands (Knight et al. 1981; Amiro et al. 2006; Zha et al. 2010; Clark et al. 2012). The low physiological functioning level of the trees and the low density of the stand (Viville et al. 1993) can explain this discrepancy. Moreover, this discrepancy can be explained considering that the simulated vegetal cover corresponds to an ideal healthy forest. However, the trees on the Strengbach watershed, especially spruces, are characterized by defoliation and signs of dieback and decline. Previous studies have reported a decreased rate of evapotranspiration caused by defoliation (Dennison et al. 2009; Clark et al. 2012).

\section{Monthly discharge at watershed outlet}

As mentioned above, the 3D hydrogeological model estimates the discharge at the outlet of the Strengbach 


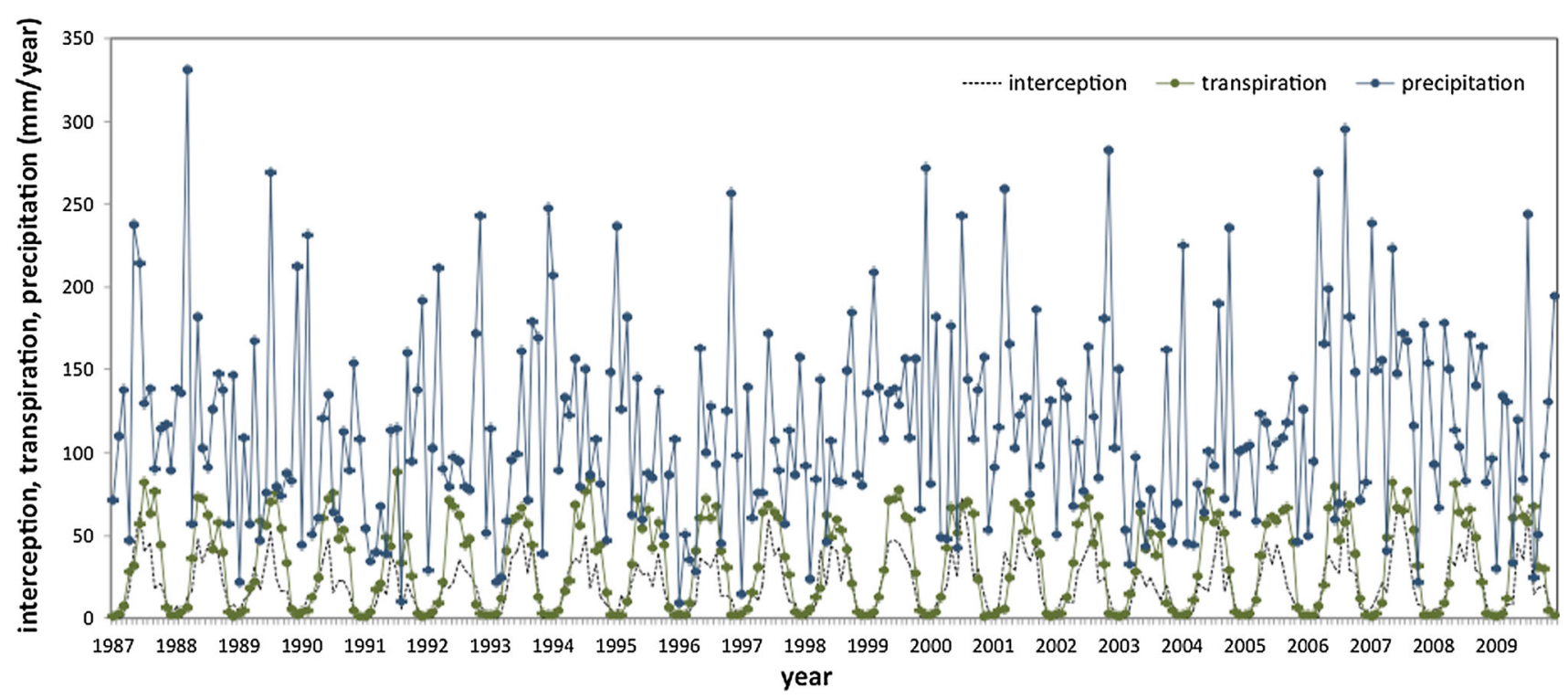

Fig. 5 Interception and transpiration calculated by LPJ model over 1987-2009 period on Strengbach catchment. Precipitation is measured on watershed since 1987

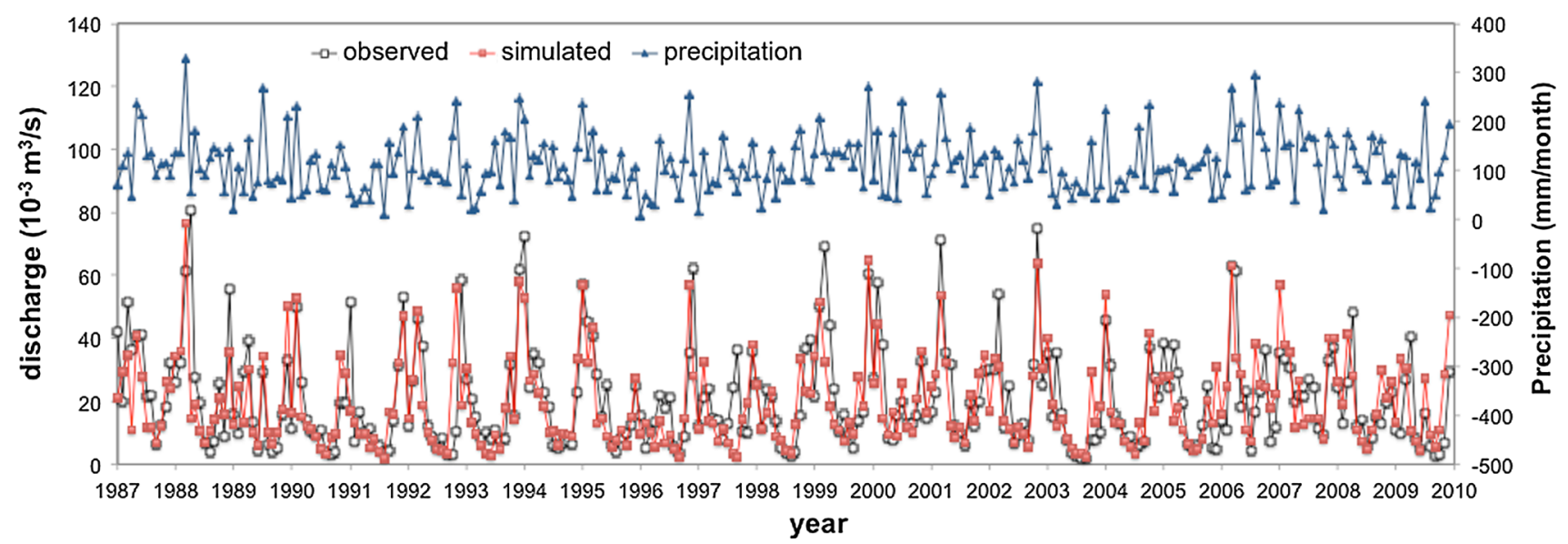

Fig. 6 Intra-annual variations in precipitation and discharge calculated by models cascade and observed on Strengbach watershed over 1987-2009 period

catchment using calculated water fluxes from the LPJ model (Fig. 6).

The Nash-Sutcliffe coefficient (NSE) and the modified index of agreement $\left(\mathrm{d}_{1}\right)$ were used to estimate the quality of discharge predictions by models cascade (Legates and McCabe 1999; McGuire et al. 2002). The NSE and $d_{1}$ values between the simulated and observed monthly discharge are equal to 0.48 and 0.68 , respectively. Strong (NSE superior to 0.7; Fig. 7a) or moderately strong (NSE superior to 0.5 ) correlations between calculated discharge and observed discharge emerged in $50 \%$ of the simulated period. The difference between simulated and measured outflow during some periods can be explained by the following:
1. an underestimation of the recharge of the watershed in autumn after a drought during spring and summer periods (Fig. 7b);

2. a snow formation during the winter period and a snowmelt in April (Fig. 7c); and

3. an overestimation of calculated evapotranspiration (Fig. 7d).

Figure 7b illustrates the first explanation, using the 2003/2004 period. The mean monthly precipitation was $61 \mathrm{~mm}$ over the February-September period of 2003 (the standard deviation is $20.1 \mathrm{~mm}$ ). The strong increase in precipitation (by $106 \mathrm{~mm}$ ) in October leads to an increase of $86 \mathrm{~mm}$ of simulated discharge. The observed discharge slightly increases (by $20 \mathrm{~mm}$ ) because of the catchment 

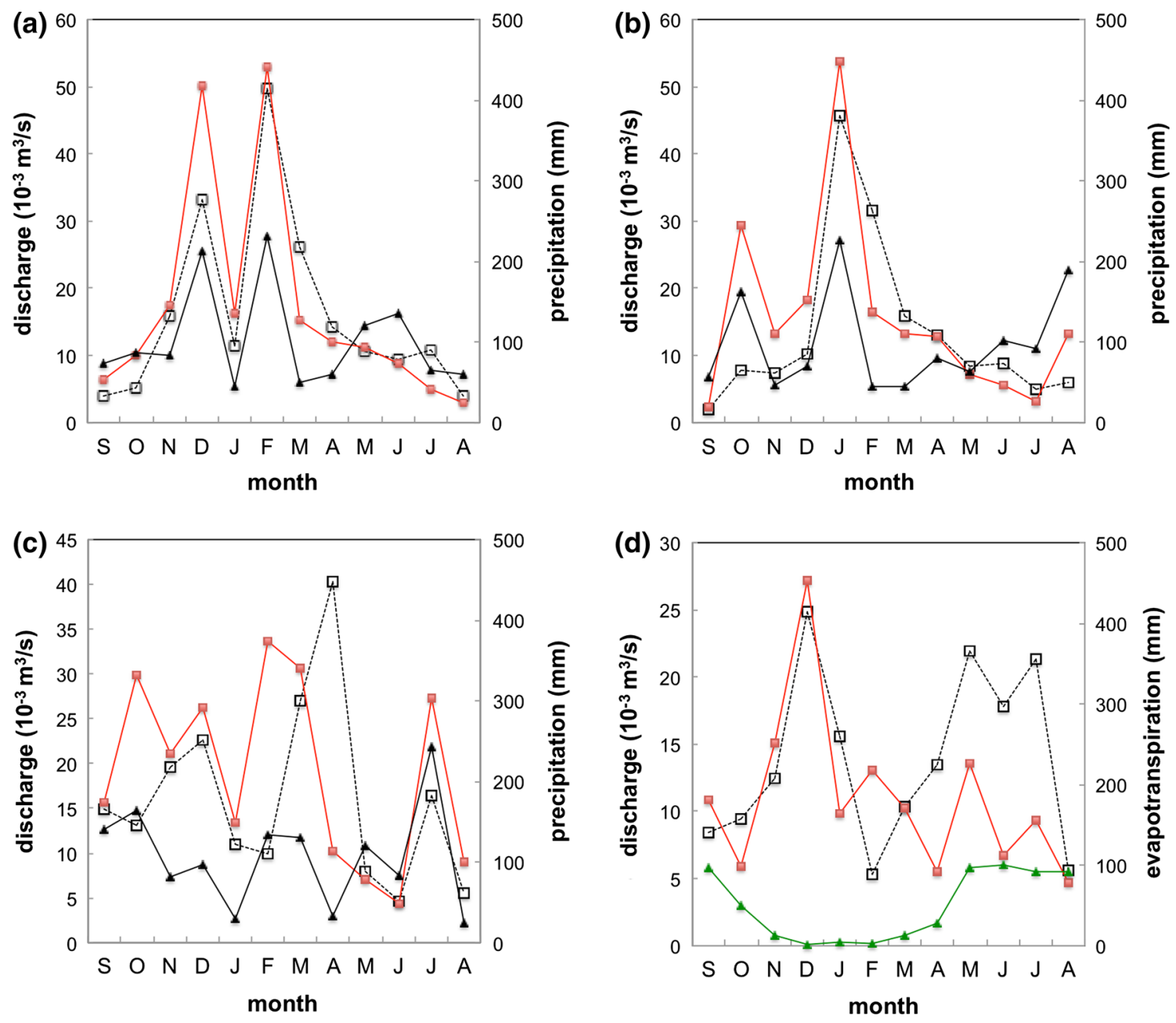

Fig. 7 Comparison of calculated (red line) and observed (dotted line) discharge during four hydrological years: 1989/1990 (a), 2003/2004 (b), 2008/2009 (c), and 1995/1996 (d). The precipitation (black line)

recharge. The recharge of the Strengbach watershed is observed during autumn after a drought period that lasted several years (for example: 1992/1993, 2005/2006, and 2008/2009). Otherwise, these differences between observed and simulated discharge could highlight a toosimplified representation of the Strengbach watershed in the hydrogeological model as the vertical discretization and the spatialization of hydraulic parameters.

The snow accumulation and snow thaw partly control the water fluxes from the autumn to the spring (explanation 2 ). Figure $7 \mathrm{c}$ highlights the importance of the two processes for the 2008/2009 period. The snow accumulation occurred in February. The measured discharge is stable, while the precipitation rate and the calculated discharge increase. Then, the snowmelt occurred in April, leading to an important increase in discharge at the outlet of the watershed. In this simulation, the snow processes are taken into account through the transpiration calculation. Indeed, the transpiration rate is calculated from the water available

and evapotranspiration (green line) are represented on $\mathbf{a}, \mathbf{b}, \mathbf{c}$ and on d respectively

in the soil and the snow processes control the soil water content (see "LPJ model").

We performed a complementary simulation (called SWithS) in which the snowmelt module of LPJ model was used to take into account accumulation and melt processes in the calculated water fluxes. Snowmelt (M) is computed using a degree-day method (Choudhury et al. 1998):

$M=(1.5+0.007 \operatorname{Pr}) T_{a}$,

where $\operatorname{Pr}$ is the precipitation amount $\left(\mathrm{mm} \mathrm{day}^{-1}\right)$, and $T_{a}$ is the daily air temperature above $0{ }^{\circ} \mathrm{C}$. The water flux from snow processes was integrated in the recharge hydrogeological equation ("Cascade of two models: LPJ model and MODFLOW model"). Figure 8 shows the comparison between the observed discharge and calculated discharge, with and without the snow module. The simulated average monthly discharge is strongly underestimated by $48 \%$ in the winter period (December to March) and is overestimated by $59 \%$ the rest of the year (Fig. 8) in the SWithS 
Fig. 8 Mean monthly discharge observed (Obs), calculated by models cascade without (SWithoutS) and with (SWithS) snow module on Strengbach watershed over 1987-2009 period

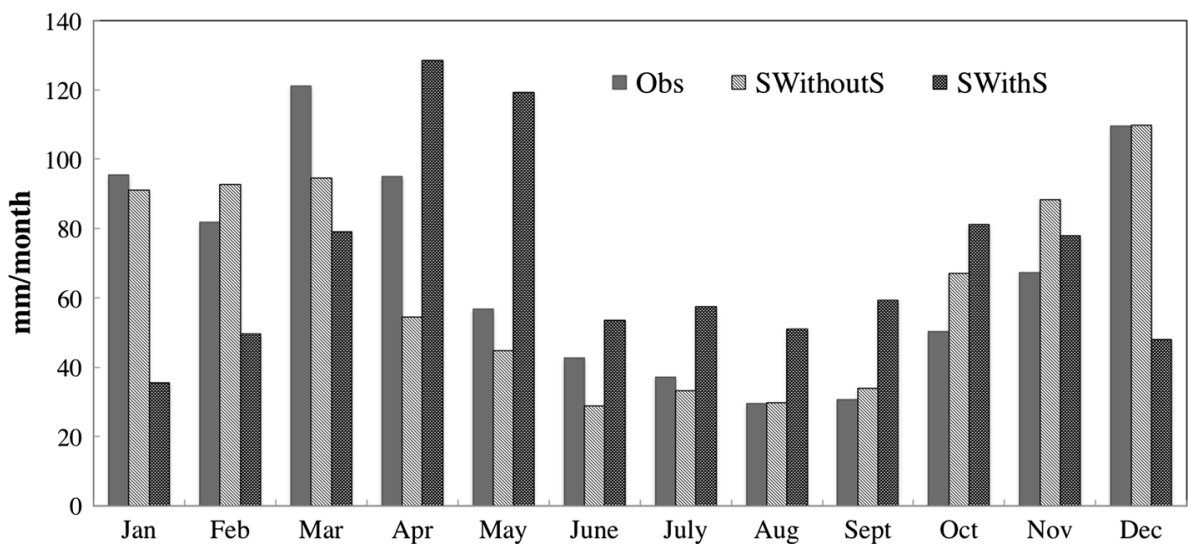

Fig. 9 a Comparison of simulated and observed discharge during the period 1987-2009. b Interannual variations in simulated and observed discharge
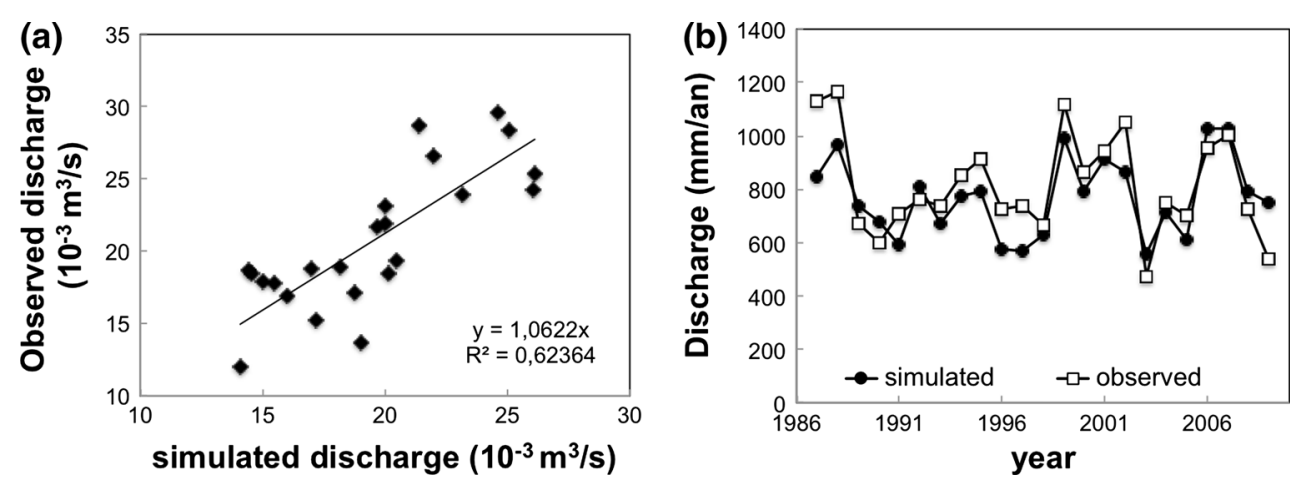

model performance at the annual scale than at the monthly scale.

Figure 9 compares the observed and simulated interannual variability of discharge over the period 1987-2009. The simulated and observed trends in river flow are significantly correlated. The simulated annual mean discharge (770.2 $\mathrm{mm} /$ year) is close to the measured value (817.6 mm/year). The mean low water discharges (from May to October) are well reproduced, with the model-data difference remaining below 3\%. The mean high water discharges (from November to April) are slightly underestimated (by 7\%) in this simulation.

In summary, the LPJ-MODFLOW models cascade is able to reproduce the water budget of the Strengbach catchment at the annual scale over two decades. At the intra-annual scale, the performance of the model declines. Therefore, in the following section, devoted to the evolution of vegetation and the water cycle over the next century, the discussion of the results will be based on annual mean values only.

\section{The hydrological response to climate change over the next century}

The A1B IPCC scenario predicts an increase in the mean annual air temperature (Fig. 10) by $2.6^{\circ} \mathrm{C}$ between 2010
The NSE and $d_{1}$ values rise to 0.56 and 0.85 , respectively, if we compare mean annual discharges, illustrating a better 
Fig. 10 Temperature and precipitation predicted over 2010-2098 period on Strengbach watershed
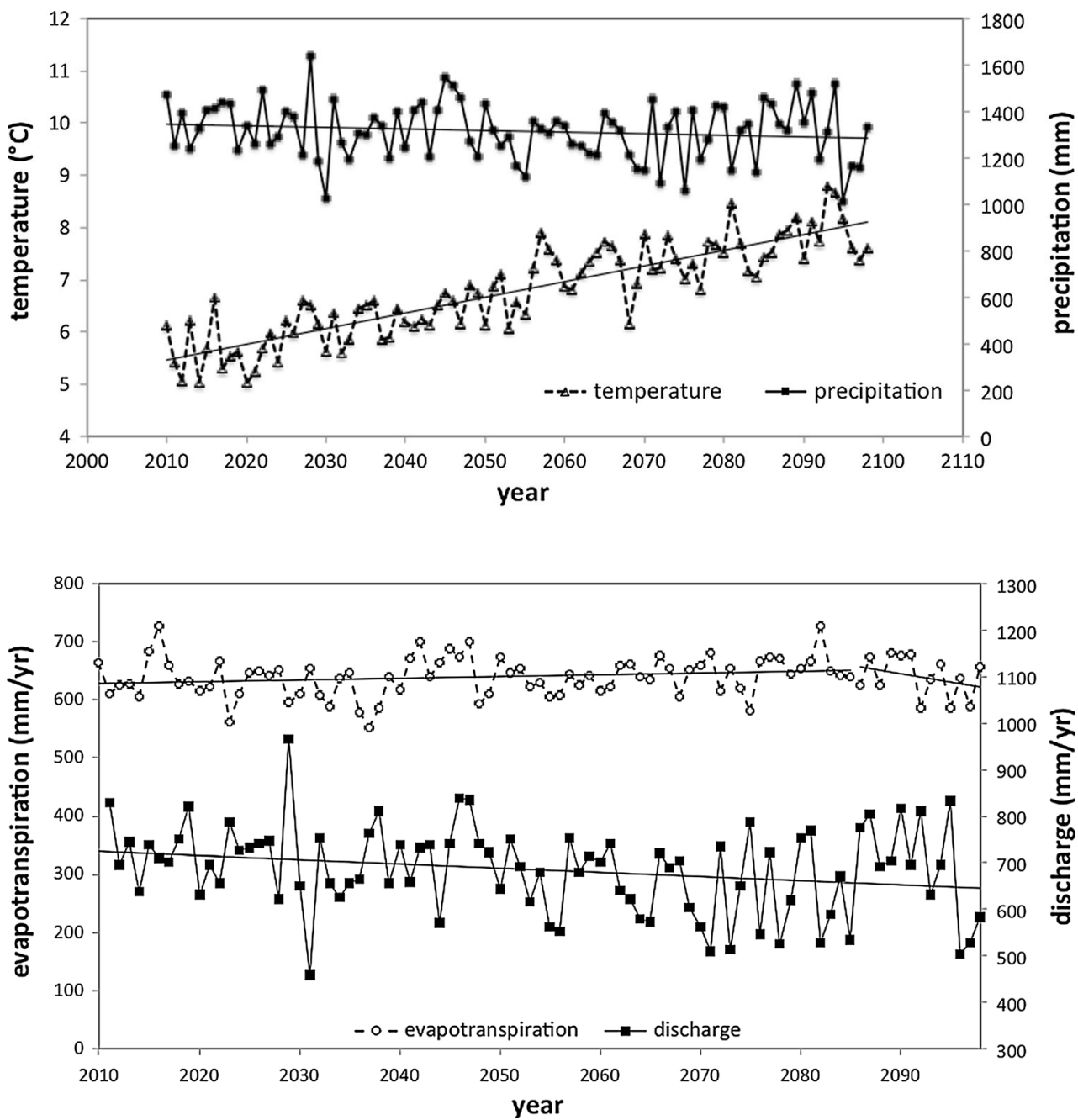

Fig. 11 Evapotranspiration and discharge estimated by models cascade over 21 st century on Strengbach catchment and 2098 over the area surrounding the Strengbach watershed, and a decrease in mean annual precipitation by approximately $4.5 \%$ (from 1346 to $1285 \mathrm{~mm} /$ year; Fig. 10).

The models cascade predicts a decrease in discharge by $11 \%$ over the 21 st century (Fig. 11). The change in hydrologic behavior partly depends on the response of the biome to climate change. The transpiration and interception calculated by the LPJ model increase slightly by 2.6 and $2.2 \%$, respectively. The mean evapotranspiration over the last 10 years of the 20 th and 21 st centuries are, respectively, 609 and $638 \mathrm{~mm} /$ year, corresponding to a $5 \%$ increase. The increase in atmospheric $\mathrm{CO}_{2}$ concentration and temperature change the rate of plant evapotranspiration (water uptake by roots and evaporation through the stomata). On the one hand, the higher temperatures could increase transpiration by changing the vapor pressure demand (Van de Geijn and Goudriaan 1997; Apple et al. 2000). On the other hand, the higher atmospheric $\mathrm{CO}_{2}$ levels could decrease the transpiration by reduction of stomatal aperture (Kreuzwieser et al. 2006; Houshmandfar et al. 2015). Indeed, plants tend to close their stomata to reduce their transpiration, leading to an increase in the intercellular $\mathrm{CO}_{2}$ pressure and eventually a more efficient use of soil moisture (Friend and Cox 1995; Van de Geijn and Goudriaan 1997).

Moreover, the simulated evapotranspiration displays two significant trends: before 2080, and after 2080.

(a) Before 2080 The decrease of discharge by $14 \%$ (Fig. 11) is related to the decrease of precipitation by $6 \%$ (Fig. 10) and an increase of evapotranspiration from 629 to $651 \mathrm{~mm}$ and then up to 2080 (Fig. 11). We calculated the precision of the evapotranspiration trend to a $90 \%$ confidence interval. The wide $90 \%$ confidence intervals of this trend $[0.01 ; 0.59]$ suggest that the calculated trend is uncertain. The evolution of evapotranspiration is not related to vegetal cover change because the LPJ model predicts a rather stable vegetal cover distribution until approximately 2080. The evapotranspiration increases by $4 \%$ because the air temperature rise promotes atmospheric 
Fig. 12 Cover percentage of plant functional type (PFT) calculated by LPJ model as a function of time on Strengbach watershed. The temperate broad-leaved summergreen and needle-leaved evergreen are merged

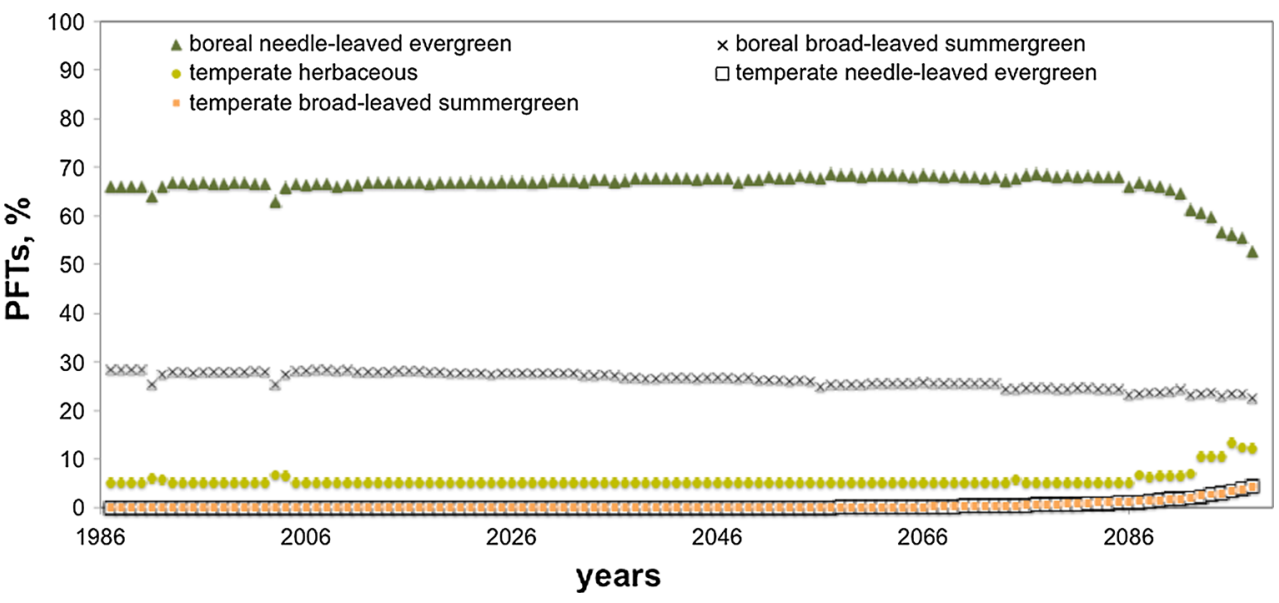

evaporative demand and consequently vegetation transpiration.

(b) After 2080 The model predicts a significant decrease of discharge by $-17 \pm 11 \mathrm{~mm} /$ year over the last 10 years of the 21 st century. This decreasing trend corresponds to a decrease in precipitation (by $-24 \pm 17 \mathrm{~mm} / \mathrm{year}$ ) and evapotranspiration (by 5\%). However, the wide $90 \%$ confidence intervals $([-7.32 ; 1.54])$ and the fact that the evapotranspiration trend spans zero suggest that the calculated trend is uncertain. The decrease in evapotranspiration over the last 10 years of 21 st century is related to the change in vegetation cover. Indeed, the model predicts a rapid decrease of the boreal evergreen forest and an increase of both temperate deciduous forests and herbaceous environments after 2080 (Fig. 12). In agreement with previous studies, the boreal forests are partly replaced by temperate forests or herbaceous environments due to the increasing occurrence of warmer winter, favoring temperate tree development. At the same time, hot summers lead to boreal forest decline (Joos et al. 2001; Lucht et al. 2006). Moreover, deciduous forests and herbaceous biomes are characterized by a lower evapotranspiration compared to evergreen forests (Zhang et al. 2001; Peters et al. 2013).

Two sensitivity tests have been performed to quantify the individual effects of increasing atmospheric $\mathrm{CO}_{2}$ concentrations and temperatures on evapotranspiration. In the first test, predictions of evapotranspiration based solely on the scenario of an increase in atmospheric $\mathrm{CO}_{2}$ concentrations were computed with a constant air temperature and precipitation rate (in 2010). The second test simulates the evapotranspiration variation with an increase in both air temperature and precipitation rate, with $\mathrm{CO}_{2}$ concentration held constant (at $390 \mathrm{ppm}$ ).

In agreement with previous studies (Friend and Cox 1995; Van de Geijn and Goudriaan 1997; Beaulieu et al. 2010), the atmospheric $\mathrm{CO}_{2}$ concentration increase (up to approximately $700 \mathrm{ppm}$ ) leads to the decrease in evapotranspiration by approximately $8 \%$ because of stomatal closure.

The vegetal cover distribution is stabilized until the 2080s. After 2080, a part of the evergreen forest cover is replaced by temperate herbaceous environment. The annual mean transpired water is equal to $408 \mathrm{~mm} / \mathrm{year}$ at the beginning of the $21 \mathrm{st}$ century and decreases to $391 \mathrm{~mm} /$ year by the end of the 21 st century, which represents a $4 \%$ decrease (Fig. 13a). This trend is in agreement with Misson et al. (2002), who found a transpiration decrease in two deciduous forest species in Belgium under doubled $\mathrm{CO}_{2}$ concentrations. The evapotranspiration decrease leads to the increase of discharge by approximately $6 \%$ (from 808 to $853 \mathrm{~mm} /$ year).

In the second test, the annual transpiration displays a significant increasing trend from 2010 to 2098, with a rate of $0.7 \pm 0.15 \mathrm{~mm} /$ year. The LPJ model predicts a rather stable vegetal cover distribution and no significant change from leaf interception during the next century (a decrease by $0.002 \mathrm{~mm} /$ year; Fig. 13b). The transpiration increase predicted by the model is consistent with the results of previous studies, which reported that the simulated annual transpiration increased due to the increase of atmospheric evaporative demand and stomatal opening (Misson et al. 2002).

The change in simulated discharge due to the transpiration change is $-0.70 \mathrm{~mm} /$ year from 2010 to 2098 .

\section{Conclusions and perspectives}

The models cascade that combines a dynamic vegetation model and a hydrogeological model is able to reproduce the vegetal cover distribution and the annual discharge at the outlet of the Strengbach watershed over the last two decades. Based on the ability of the model to reproduce recent past conditions, we explore the response of the 
Fig. 13 Simulation of transpiration, interception and discharge for the 21 st century in the Strengbach watershed for a increased atmospheric $\mathrm{CO}_{2}$ concentration, and $\mathbf{b}$ increased temperature

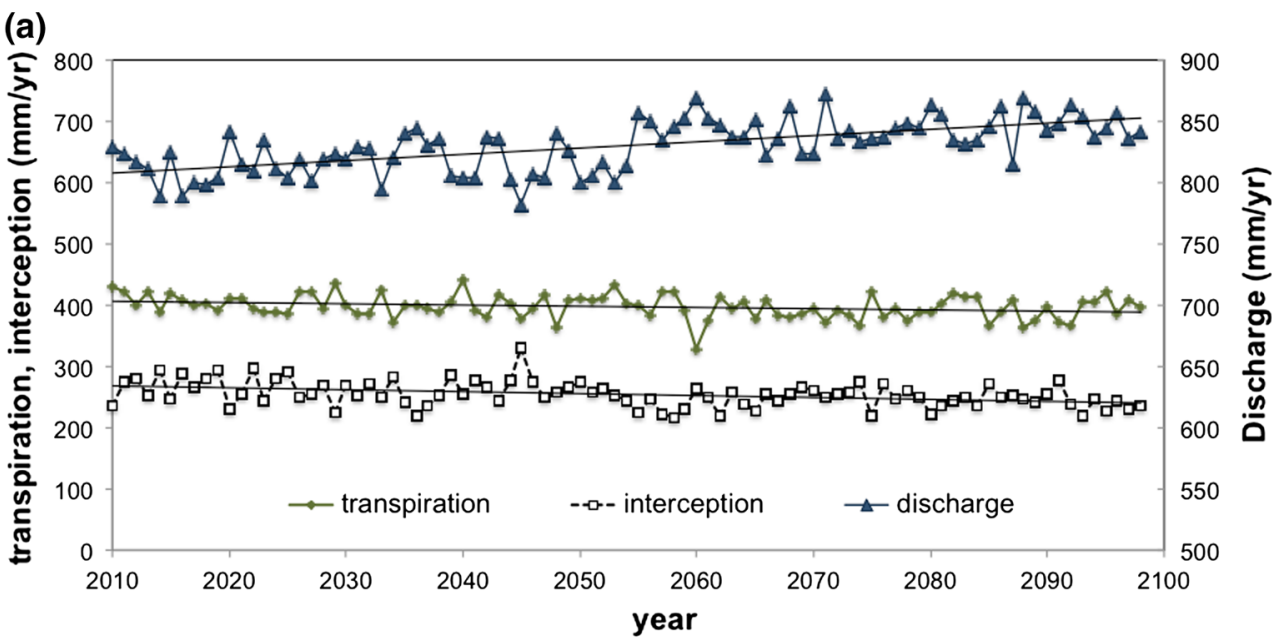

(b)

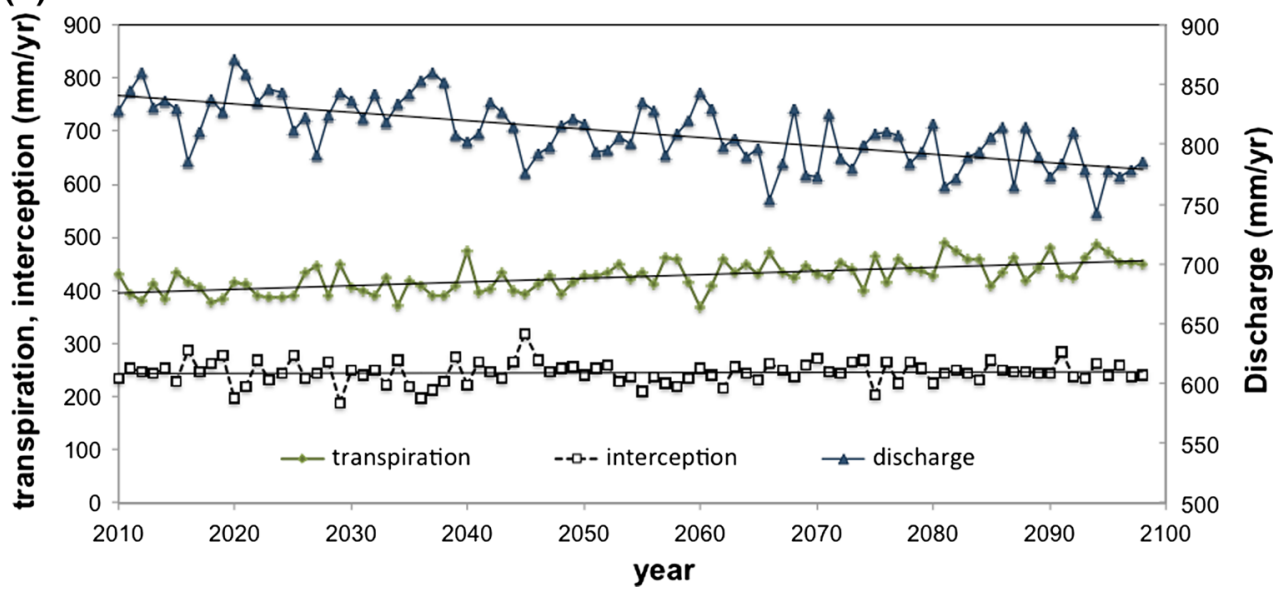

Strengbach water budget to the future climate (21st century).

The salient results are as follows:

1. Climate change (A1B IPCC scenario) over future decades leads to a decrease in discharge by $11 \%$, principally controlled by a reduction in precipitation. The evapotranspiration variations due to plant physiology and vegetal cover changes are not significant.

2. The impact of increased air temperature on land plants offsets the impact of increased atmospheric $\mathrm{CO}_{2}$ concentration. Therefore, the simultaneous increase of these two climatic parameters seems to minimize the effects of climate change on discharge evolution. This conclusion is in agreement with previous studies, which demonstrated that manipulation of single factors often lead to stronger response of land plants than multi-factor experiments caused by complex and nonlinear process interactions (Zhou et al. 2006; Luo et al. 2008). The predicted variations remain very close to the uncertainties of the model used.
3. The simultaneous decrease of evapotranspiration and precipitation leads to a significant decrease of discharge $(26 \%)$ over the later years of the 21 st century.

Based on our simulations, it seems that the response of land plants to climate change in the future may not strongly affect the water resources in the Strengbach catchment. These simulations represent preliminary results in the study of regional impacts of climate change. However, the models still suffer from some shortcomings, and lack (1) a better representation of snow storage and melt, (2) data related to the calcium and magnesium nutrient cycle, which was included in the biospheric model to simulate forest decline, and (3) more detailed knowledge of hydraulic parameters in heterogeneous soils.

Future research should include further modelling of the Strengbach catchment using different scenarios of climate change, including modelling with low (A1/B1 scenario) or high (A2/B2 scenario) carbon dioxide emissions as well as simulations at shorter time scales, such as daily or weekly, rather than monthly simulations. 
Acknowledgements This work has been funded by the $\mathrm{EC} 2 \mathrm{CO} /$ INSU-CNRS project "Dynamique hydrogéochimique d'un basin versant à l'échelle décennale". Alain Clément (Laboratoire d'Hydrologie et de Géochimie de Strasbourg, Strasbourg) is greatly acknowledged for numerical coding.

\section{References}

Abdelaziz R, Merkel BJ (2015) Sensitivity analysis of transport modelling in a fractured gneiss aquifer. J Afr Earth Sci 103:121-127

Amiro BD, Barr AG, Black TA, Iwashita H, Kljun N, McCaughey JH, Morgenstern K, Murayama S, Nesic Z, Orchansky AL, Saigusa $\mathrm{N}$ (2006) Carbon, energy and water fluxes at mature and disturbed forest sites, Saskatchewan, Canada. Agric For Meteorol 136:237-251

Apple ME, Olszyk DM, Ormrod DP, Lewis J, Southworth D, Tingey DT (2000) Morphology and stomatal function of Douglas fir needles exposed to climate change: elevated $\mathrm{CO}_{2}$ and temperature. Int J Plant Sci 161:127-132

Arnell NW (1999) The effect of climate change on hydrological regimes in Europe: a continental perspective. Glob Environ Chang 9:5-23

Arnell NW, Gosling SN (2013) The impacts change on river flow regimes at the global scale. J Hydrol 486:351-364

Bavay M, Grûnewald T, Lehning M (2013) Response of snow cover and runoff to climate change in high Alpine catchments of Eastern Switzerland. Adv Water Resour 55:4-16

Beaulieu E, Goddéris Y, Labat D, Roelandt C, Oliva P, Guerrero B (2010) Impact of atmospheric $\mathrm{CO}_{2}$ levels on continental silicate weathering. Geochem Geophys Geosyst 11:1-18

Betts RA, Cox PM, Lee SE, Woodward FI (1997) Contrasting physiological and structural vegetation feedbacks in climate change simulations. Nature 387:796-799

Björnsen Gurung A (2007) Global change in mountain regionsresearch strategy. The Mountain Research Initiative (MRI), Zürich

Bocchiola D (2014) Long term (1921-2011) hydrological regime of Alpine catchments in Northern Italy. Adv Water Resour 70:51-64

Boucher M, Pierret MC, Dumont M, Viville D, Legchenko A, Chevalier A, Pez S (2015) MRS characterization of a mountain hard rock aquifer: the Strengbach Catchment. In: 6th international workshop on Magnetic resonance in the subsurface, Aarhus University, Aarhus, Denmark

Boutin R, Montigny R, Thuizat R (1995) Chronologie K-Ar et ${ }^{39} \mathrm{Ar} /{ }^{40} \mathrm{Ar}$ du métamorphisme et du magmatisme des Vosges. Comparaison avec les massifs varisques avoisinants et determination de l'âge de la limite Viséen inférieur-viséen supérieur. Géol Fr 1:3-25

Carlsson A, Olsson T (1977) Hydraulic properties of Swedish crystalline rocks-hydraulic conductivity and its relation to depth. Bull Geol Inst Univ Upps 7:71-84

Chabaux F, Riotte J, Schmitt AD, Carignan J, Herckes P, Pierret MC, Wortham H (2005) Variations of $\mathrm{U}$ and $\mathrm{Sr}$ isotope ratios in Alsace and Luxembourg rain waters: origin and hydrogeochemical imlications. C R Geosci 337:1447-1456

Cho J, Barone VA, Mostaghimi S (2009) Simulation of land use impacts on groundwater levels and streamflow in a Virginia watershed. Agric Water Manag 96(1):1-11

Choudhury BJ, DiGirolamo NE, Susskind J, Darnell WL, Gupta SK, Asrar G (1998) A biophysical process-based estimate of global land surface evaporation using satellite and ancillary data-II.
Regional and global patterns seasonal and annual variations. J Hydrol 205:186-204

Churkina G, Running SW, Schloss AL (1999) The participants of the Potsdam NPP model intercomparison 1999. Comparing global models of terrestrial net primary productivity (NPP): the importance of water availability. Glob Chang Biol 5((Suppl. 1)):46-55

Clark KL, Skowronski N, Gallagher M, Renninger H, Schäfer K (2012) Effects on invasive insects and fire on forest energy exchange and evapotranspiration in the New Jersey pinelands. Agric For Meteorol 166-167:50-61

Dennison PE, Nagler PL, Hultine KR, Glenn EP, Ehleringer JR (2009) Remote monitoring of tamarisk defoliation and evapotranspiration following saltcedar leaf beetle attack. Remote Sens Environ 113:1462-1472

Déqué M (2007) Frequency of precipitation and temperature extremes over France in an anthropogenic scenario: model result and statistical correction according to observed value. Glob Planet Chang 57:16-26

Dunn SM, Mackay R (1995) Spatial variation in evapotranspiration and the influence of land "use on catchment hydrology. J Hydrol 171:49-73

Fan M, Shibata H (2015) Simulation of watershed hydrology and stream water quality under land use and climate change scenarios in Teshio River watershed, northern Japan. 2015. Ecol Indic 50:79-89

Field CB, Jackson RB, Mooney HA (1995) Stomatal responses to increased $\mathrm{CO}_{2}$ : implications from the plant to the global scale. Plant Cell Environ 18:1214-1225

François LM, Delire C, Warnant P, Munhoven G (1998) Modelling the glacial-interglacial changes in the continental biosphere. Glob Planet Chang 16-17:37-52

Friend AD, Cox PM (1995) Modelling the effects of atmospheric $\mathrm{CO} 2$ on vegetation-atmosphere interactions. Agric For Meteorol 73:285-295

Gangloff S, Stille P, Pierret M-C, Weber T, Chabaux F (2014) Characterization and evolution of dissolved organic matter in acidic forest soil and its impact on the mobility of major and trace elements (case of the Strengbach watershed). Geochim Cosmochim Acta 130:21-41

Gerakis A, Baer B (1999) A computer program for soil textural classification. Soil Sci Soc Am J 63:807-808

Gerten D, Schaphoff S, Haberlandt U, Lucht W, Sitch S (2004) Terrestrial vegetation and water balance: hydrological evaluation of a dynamic global vegetation model. J Hydrol 286:249-270

Goddéris Y, François LM, Probst A, Schott J, Moncoulon D, Labat D, Viville D (2006) Modelling weathering processes at the catchment scale: the WITCH numerical model. Geochim Cosmochim Acta 70:1128-1147

Harris I, Jones PD, Osborn TJ, Lister DH (2014) Updated highresolution grids of monthly climatic observations-the CRU TS3.10 Dataset. Int J Climatol 34:623-642

Haxeltine A, Prentice IC (1996) BIOME 3: an equilibrium terrestrial biosphere model based on ecophysiological constraints, resource availability, and competition among plant functional types. Glob Biogeochem Cycles 10(4):693-709

Heath JC (1983) Basic ground-water hydrology. US Geological Survey Water-Supply Paper 2220, 86

Heath MJ, Durrance EM (1985) Hydrogeological investigations at an experimental site in granite, South West England, in relation to the transport of radionuclides through fractured rock. Nucl Chem Waste Manag 5:251-267

Houshmandfar A, Fitzgerald GJ, Tausz M (2015) Elevated CO2 decreases both transpiration flow and concentrations of $\mathrm{C}$ and $\mathrm{Mg}$ in the xylem sap of wheat. J Plant Physiol 174:157-160 
IPCC (2014) Climate Change 2014: Synthesis Report. Contribution of Working Groups I, II and III th the Fifth Assessment Report of the Intergovernmental Panel on Climate Change [Core Writing Team, R.K. Pachauri and L.A. Meyer (eds)]. IPCC, Geneva, Switzerland

Joos F, Prentice IC, Sitch S, Meyer R, Hooss G, Plattner G-K, Gerber S, Hasselmann K (2001) Global warming feedbacks on terrestrial carbon uptake under the Intergovernmental Panel on Climate Change (IPCC) emission scenarios. Glob Biogeochem Cycles 15:891-907

Kaplan JO (2001) Geophysical applications of vegetation modeling. $\mathrm{PhD}$ Thesis. University of Lund

Knight DH, Fahey TJ, Running SW, Harrison AT, Wallace LL (1981) Transpiration from 100-yr-old lodgepole pine forests estimated with whole-tree photometers. Ecology 62:717-726

Kreuzwieser J, Rennenberg H, Steinbrecher R (2006) Impact of shortterm and long-term elevated $\mathrm{CO}_{2}$ on emission of carbonyls from adult Quercus petraea and Carpinus betulus trees. Environ Pollut 142:246-253

Ladouche B, Probst A, Viville D, Idir S, Baqué D, Loubet M, Probst JL, Bariac T (2001) Hydrograph separation using isotopic, chemical and hydrological approaches (Strengbach catchment, France). J Hydrol 242:255-274

Le Goaster S, Dambrine E, Ranger J (1991) Croissance et nutrition minérale d'un peuplement d'épicéa sur sol pauvre. I Evolution de la biomasse et dynamique d'incorporation d'éléments minéraux. Acta Oecol 12:771-789

Legates DR, McCabe GJ Jr (1999) Evaluating the use of "goodnessof-fit" measures in hydrologic and hydroclimatic model validation. Water Resour Res 35:233-241

Legchenko A, Descloitres M, Vincent C, Guyard H, Garambois S, Chalikakis K, Ezersky M (2011) Three-dimensional magnetic resonance imaging for groundwater. New J Phys 13:025022

Leipprand A, Gerten D (2006) Global effects of doubled atmospheric $\mathrm{CO}_{2}$ content on evapotranspiration, soil moisture and runoff under potential natural vegetation. Hydrol Sci J 51:171-185

Lucas Y, Vaute L (2011) Spatialized approach in the hydrogeological modeling of an abandoned mining sector. $\mathrm{J}$ water sci 24(1):77-85

Lucht W, Prentice IC, Myneni RB, Sitch S, Friedlingstein P, Cramer W, Bousquet P, Buermann W, Smith B (2002) Climatic control of the high-latitude vegetation greening trend and Pinatubo effect. Science 296:1687-1689

Lucht W, Schaphoff S, Erbrecht T, Heyder U, Cramer W (2006) Terrestrial vegetation redistribution and carbon balance under climate change. Carbon Balance Manag 1:6. doi:10.1186/17500680-1-6

Luo Y, Gerten D, Weng E, Zhou X, Parton WJ, Le Maire G, Keough C, Beier C, Ciais P, Dukes JS, Emmett BA, Hanson PJ, Knapp A, Linder S, Nepstad D, Rustad L (2008) Modelled interactive effects of precipitation, temperature, and $\mathrm{CO}_{2}$ on ecosystem carbon and water dynamics in different climatic zones. Glob Chang Biol 14:1986-1999

Luo Y, Ficklin DL, Liu X, Zhang M (2013) Assessment of climate change impacts on hydrology and water quality with a watershed modeling approach. Sci Total Environ 450-451:72-82

Maréchal JC, Perrochet P (2003) Nouvelle solution analytique pour l'étude de l'interaction hydraulique entre les tunnels alpins et les eaux souterraines. Bull Soc Géol Fr 174(5):441-448

Maréchal JC, Wyns R, Lachassagne P, Subrahmanyam K, Touchard F (2003) Anisotropie vertical de la perméabilité de l'horizon fissure des aquifers de socle: concordance avec la structure géologique des profils d'altération. Geosci Surf/Hydrol Hydrogeol 335:451-460

McDonald MG, Harbaugh AW (1988) A Modular Three-dimensional Finite-difference Groung-water Flow Model In Techniques of
Water-Resources Investigations of US Geological Survey. Book 6, CH.A1, Reston, Virginia

McGuire KJ, DeWalle DR, Gburek WJ (2002) Evaluation of mean residence time in subsurface waters using oxygen-189 fluctuations during drought condition in the mid-Appalachians. J Hydrol 261:132-149

Milly PCD (1997) Sensitivity of greenhouse summer dryness to changes in plant rooting characteristics. Geophys Res Lett 24:269-271

Misson L, Rasse DP, Vincke C, Aubinet M, François L (2002) Predicting transpiration from forest stands in Belgium for the 21st century. Agric For Meteorol 111:265-282

Morán-Tejeda E, Zabalza J, Rahman K, Gago-Silva A, López-Moreno JI, Vicente-Serrano S, Lehmmann A, Tague CL, Beniston M (2014) Hydrological impacts of climate and land-use changes in a mountain watershed: uncertainty estimation based on model comparison. Ecohydrology. doi:10.1002/eco.1590

Morison JIL, Gifford RM (1983) Stomatal sensitivity to carbon dioxide and humidity. Plant Physiol 71:789-796. doi:10.1104/ pp.71.4.789

Morrice JA, Valett HM, Dahm CN, Campana ME (1997) Alluvial characteristics, groundwater-surface water exchange and hydrological retention in headwater streams. Hydrol Process 11:253-267

Peel MC, McMahon TA, Finlayson BL, Watson FGR (2001) Identification and explanation of continental differences in the variability of runoff. J Hydrol 250:224-240

Peters EB, Hiller RV, McFadden JP (2013) Seasonal contributions of vegetation types to suburban evapotranspiration. J Geophys Res 116:1-18

Pierret MC, Stille P, Prunier J, Viville D, Chabaux F (2014) Chemical and U-Sr isotopic variations in stream and source waters of the Strengbach watershed (Vosges Mountains; France). Hydrol Earth Syst Sci 18:3969-3985

Rasmussen WC (1964) Permeability and storage of heterogeneous aquifers in the United States. Int Assoc of Sci Hydrol 64:317-325

Rihs S, Prunier J, Thien B, Lemarchand D, Pierret MC, Chabaux F (2011) Using short-lived nuclides of the U- and Th-series to probe the kinetics of colloid migration in forested soils. Geochim Cosmochim Acta 75:7707-7724

Riotte J, Chabaux $\left.\mathrm{F}(1999){ }^{234} \mathrm{U} /{ }^{238} \mathrm{U}\right)$ activity ratios in freshwaters as tracers of hydrological processes: the Strengbach watershed (Vosges, France. Geochim Cosmochim Acta 63:1263-1275

Sieber A, Uhlenbrook S (2005) Sensitivity analyses of a distributed catchment model to verify the model structure. J Hydrol 310:216-235

Sitch S, Smith B, Prentice IC, Arneth A, Bondeau A, Cramer W, Kaplan JO, Levis S, Lucht W, Sykes MT, Thonicke K, Venevsky S (2003) Evaluation of ecosystem dynamics, plant geography and terrestrial carbon cycling in the LPJ dynamic global vegetation model. Glob Chang Biol 9(2):161-185. doi:10.1046/ j.1365-2486.2003.00569.x

Spitz K, Moreno J (1996) A practical guide to groundwater and solute transport modeling. Wiley, NY

Stephenson NL (1990) Climatic control of vegetation distribution: the role of the water balance. Am Nat 135:649-670

Stober I (1997) Permeabilities and chemical properties of water in crystalline rocks of the Black Forest, Germany. Aquat Geochem 3:43-60

Van de Geijn SC, Goudriaan J (1997) Changements du climat et production agricole. U N Food and Agriculture Organization, Rome

Viville D, Biron P, Granier A, Dambrine E, Probst A (1993) Interception in a mountainous declining spruce stand in the Strengbach catchment (Vosges, France). J Hydrol 144:273-282 
Viville D, Ladouche B, Bariac T (2006) Isotope hydrological study of mean transit time in the granitic Strengbach catchment (Vosges massif, France): application of the FlowPC model with modified input function. Hydrol Process 20:1737-1751

Viville D, Chabaux F, Stille P, Pierret MC, Gangloff S (2012) Erosion and weathering fluxes in granitic basins: the example of the Strengbach catchment (Vosges massif, eastern France). Catena 92:122-129

Vouillamoz JM, Lawson FMA, Yalo N, Descloitres M (2015) Groundwater in hard rocks of Benin: regional storage and buffer capacity in the face of change. J Hydrol 520:379-386

Woodward FI (2002) Potential impacts of global elevated $\mathrm{CO}_{2}$ concentrations on plants. Plant Biol 5:207-211

Xu X, Huang G, Zhan H, Qu Z, Haung Q (2012) Integration of SWAP and MODFLOW-2000 for modeling groundwater dynamics in shallow water table areas. J Hydrol 412-413:170-181
Zha T, Barr AG, van der Kamp G, Black TA, McCaughey JH, Flanagan LB (2010) Interannual variation of evapotranspiration from forest and grassland ecosystems in western Canada in relation to drought. Agric For Meteorol 150:1476-1484

Zhang L, Dawes WR, Walker GR (2001) Response of mean annual evapotranspiration to vegetation changes at catchment scale. Water Resour Res 37:701-708

Zhou X, Sherry RA, An Y, Wallace LL, Luo YQ (2006) Main and interactive effects of warming, clipping, and doubled precipitation on soil $\mathrm{CO}_{2}$ efflux in a grassland ecosystem. Glob Biogeochem Cycles 100:GB1003. doi:10.1029/2005GB002526 